\title{
Effective Use of Remote Learning in Sustaining Teaching and Learning of Fine and Applied Arts in COVID-19 Era in Colleges of Education
}

Christopher Ifeanyi lbenegbu ( $\nabla$ christopher.ibenegbu@unn.edu.ng )

University of Nigeria Faculty of Education https://orcid.org/0000-0002-2394-3787

Juliet Bih Angu

University of Nigeria Faculty of Education

\section{Research Article}

Keywords: COVID-19, Remote learning, Fine and Applied Arts

Posted Date: December 1st, 2021

DOI: https://doi.org/10.21203/rs.3.rs-1072579/v1

License: (c) (1) This work is licensed under a Creative Commons Attribution 4.0 International License.

Read Full License 


\section{EFFECTIVE USE OF REMOTE LEARNING IN SUSTAINING TEACHING AND LEARNING OF FINE AND APPLIED ARTS IN COVID-19 ERA IN COLLEGES OF EDUCATION}

\section{Introduction}

Coronavirus sickness (covid-19) is an infectious illness because of a newly found coronavirus. The majority who fall unwell with COVID-19 will revel in trivial to slight signs and symptoms and recover without a vivid remedy. The virus that causes COVID-19 especially spread via droplets generated while an infected person coughs, sneezes, or exhales. These droplets are too heavy to grasp inside the air and fast fall on flooring or surfaces. One can settle the ailment via respiratory within the virus if humans are inside proximity of someone who has COVID-19, or by touching an infected surface after which someone's eyes, nostril or mouth. Covid-19 is an unusual strain of coronavirus infection because of excessive acute respiration syndrome coronavirus 2 (SARS-CoV-2) (Mayo Clinic, 2020). Covid-19 broke out in Wuhan, China on December 30, 2019. Because it came about in 2019, the World Health Organization (WHO) gave it the term COVID-19. It became declared as an international pandemic on March 11, 2020 (World Health Organization (WHO), 2020).

With the outbreak of the pandemic, governments across continents took very strict measures centred on containing the spread of the virus. Among those measures taken, the indefinite closure of public settings like places of work, banks, markets, commercial centres, banks and establishments of learning like secondary faculties, colleges of education, universities, and different tertiary institutions became a part of it (World Bank, 2020). Research has shown that as of September 30, 2020, about 1.077 billion trainees are currently affected because the federal government closed the schools in response to the disease. According to UNICEF observations, 53 nations are currently imposing national closures and 27 are commanding neighbourhood closures, affecting about 61.6 percent of the world's 
learned population, whilst 72 international locations' colleges are currently open (UNESCO, 2020a).

Remote learning is where the student and the teacher, or data supply, are not bodily present in a conformist classroom setting. Information is conveyed through technology, which includes discourse forums, videoconferencing, and online assessments. Remote learning ensues synchronously with immediate, peer-to-peer relationships and partnership or asynchronously with self-paced getting to know learning that takes place individualistically of the teacher. Remote learning can be done synchronously, with every person online either at the same time or asynchronously, with students gaining access to the equal lesson at distinctive times. However, it also permits lecturers and college students to hold connections and experience part of a collection, which is more vital now than ever. With younger college students, asking parents to supervise asynchronous learning can be a catastrophe.

College closures affected no longer the most effective students and instructors' academic activities but also households (Bao, Qu, Zhang, Hogan \& Tiffany, 2020). The effect became greater extreme for deprived children and their families, inflicting interrupted getting to know, compromised vitamins, childcare problems, and consequent monetary price to families who couldn't paintings (UNESCO, 2020a). in response to school closures, UNESCO endorsed the usage of distance gaining knowledge of programmes, which is likewise referred to as remote studying and open instructional applications and platforms that colleges and teachers can use to attain freshmen remotely and restrict the disruption of schooling (UNESCO, 2020b). Distance education, also referred to as distance learning or remote studying, is the training of students who won't usually be a bodily gift at a college. Traditionally, this involved correspondence guides wherein the student corresponded with the college via put up. Nowadays, it entails online training. Faraway gaining knowledge refers to academic activities which have a ramification of formats and strategies, most of which take 
place online. There are several online alternatives available for speaking with college students, gathering assignments, and distributing academic material. Remote learning occurs whilst the learner and instructor, or supply of information, are separated with the aid of time and distance and therefore can not meet in a traditional classroom placing. Records are normally transmitted through generation (electronic mail, discussion boards, videoconference, and audio bridge) so that no physical presence in the classroom is needed; in any other case, it would be hybrid or combined mastering. Remote studying can arise synchronously or asynchronously.

The commonplace functions of any shape of remote gaining knowledge of are the instructor-learner separation with the aid of space or time, or each, and using media and technology to allow communique and trade of the studying procedure. Far-flung mastering gives novices who are not in a physical region for in-character training, access to online educational materials. This will be completed through print-primarily based mastering substances, or one-manner huge broadcasting (TV and radio programmes), or via the webbased exchange the use of social media channels, or gaining knowledge of platforms.

The achievement of far off getting to know lies in a supportive infrastructure maintained via the district, administrators, and instructors alike. Remote gaining knowledge of works best whilst all gears within the gadget are turning nicely and efficiently while each element of the education world is prepared and prepared to help each other in the technical and general fine details of faraway gaining knowledge of.

Going by this selection, far off studying calls for now not the handiest electricity however additionally get the right of entry to both statistics connectivity and the devices like smartphones, tablets, laptop's, laptops, TV, and radio via which the learning materials may be accessed. These are in quick delivery in many components of Africa (eLearning Africa, 
2020). in Nigeria, the adoption of faraway mastering within the coaching and getting to know process throughout and after the lockdown, at all degrees of schooling and subject suffered a few setbacks. That is because of inaccessibility, unavailability and price related to its infrastructures vital for remote gaining knowledge of (Onyema, Nwafor, Obafemi, Shuvro, Atonye, Aabha \& Alhuseen, 2020). Other than the value, bad power delivery, distractions, network troubles and bad virtual capabilities on the part of instructors had been additionally many of the many demanding situations hindering the powerful use of faraway gaining knowledge of (Onyema et al., 2020). Because of these and many problems, educators, freshmen and parents could not correctly make use of the potentials of far-flung getting to know.

Like each different instructional programme, pleasant and implemented arts turned into now not exempted from the many challenges currently hindering effective use of farflung gaining knowledge of. Stewart (2006) posit that coaching practical artwork publications like first-class and carried out arts through distance getting to know has usually been an undertaking for each teacher and student because exceptional and carried out arts courses require that students create and post visual substances for evaluation and statement. College students may additionally find it hard to develop to an internet environment that is predominantly textual content-primarily based. Using multimedia, together with these slides shows, will beautify the gaining knowledge of the experience of auditory and visual freshmen. Multimedia (pictures, audio and video) on the internet has made it possible to train visual art in a virtual environment (Barbara \& Leong, 2020). But, they have documented little regarding teaching visible art online. Incorporating multimedia (textual content, photos, audio and video) offers extra possibilities to supply an enriched mastering environment to online students. 
Even though there are already current troubles facing great and implemented arts schooling in Nigerian schools of schooling. Prominent among them are the lack of qualified artwork instructors, insufficient teaching facilities and funding, poor government and societal attitude toward the issue among others. Lee (2020) mentioned that arts are critical, but enrichment training frequently contains physical substances, organized sports, or even audiences. The requirements for first-rate and carried out arts coaching and getting to know necessities are not effortlessly met in digital environments. Teachers normally serve over one grade and classes that require differentiated lecture plans.

There are a few apparent dangers to run online in great and carrying out arts. Considerably, the dearth of face-to-face contact between academics and students, and losing the interaction between college students that paperwork an important part of any study roombased enjoy is lacking. Despite the efforts of the schools to foster an immersive and educational environment, the branch also acknowledges that it cannot replicate remotely a few instructions and reviews and may adjust its elegance offerings thus. All efforts need to be made for mediums and materials to be designed for extra conducive to remote learning and more accessible for college kids at domestic. In place of darkroom photography, lecturers can educate digital photography online. In addition, the branch can change printmaking courses that use an etching facility for using woodcut or a one-of-a-kind printmaking method that can be achieved at domestic.

Though, Stewart (2020) located that any potential negative aspects are some distance outweighed with the aid of the advantages. In the online studio, the lecturer can supply as much time as is important to college students and can deliver him or her alongside at a tempo, which is proper to them as people. The lecturers can confer and are looking for each other's recommendations about pupil's paintings and development. It has continually been the academics keen to strain that they no longer keep in mind the availability superior to the 
lecture room enjoyment. What they provide is flexibility. But, the blessings encompass the truth that the students do now not must compete with their peers for teachers' attention or bear the distractions that may occasionally be a part of the group experience.

To facilitate their attempt, the first-class and implemented arts branch in schools of education within the look at the area will even use productivity software called Padlet with which college students can seamlessly proportion their paintings for in-magnificence reviews and construct expert portfolios. Scanga (2020) emphasized that scholars will discover ways to percentage their works online. That is an essential ability for graphic designers, photographers, and artists who make public commissions.

Regardless of all these troubles, the outbreak of the COVID-19 pandemic served as a revelation to every stakeholder of exceptional and applied arts training, at the want for them to reposition all this is required for the powerful use of far-flung studying in the teaching of fine and applied arts in colleges of education in Nigeria. Michael Moore hooked up the concept of transactional distance in 1980. This theory articulates the idea that distance education is not certainly a geographic separation of rookies and instructors, but is a pedagogical concept. More factors out that once speaking approximately distance schooling is talking approximately a teaching environment wherein the separation between the teacher and learner are substantial enough that unique teaching-gaining knowledge of strategies and strategies need to be used. With this, it turned out it was possible to use far-flung studying to train pleasant and applied arts to preserve its schooling. Though, this turned into no longer without some problems. This is this look at. Right here, the researchers created a complete overview of distance mastering, replete with faraway learning examples, descriptions of how far off studying works, reasons of many styles of distance gaining knowledge of, examples of faraway mastering, analysis of the advantages and downsides surrounding distant learning, and greater. 


\section{Research Questions}

1. What are the available ICT devices that provide the best prospect for teaching fine and applied arts?

2. What is the effective technique used for teaching fine and applied arts in remote learning?

3. Are there challenges concerning the use of technology in the teaching of fine and applied arts?

4. Are there solutions in mitigating the adverse effect of COVID-19 lockdown on the teaching of fine and applied arts?

\section{Hypotheses}

1. The relationship between participants and ICT devices that provides the best prospect for the teaching of fine and applied arts is not statistically significant.

2. There is no significant relationship between participants and effective techniques used for the teaching of fine and applied arts in remote learning.

3. The relationship between participants and challenges concerning the use of technology in the teaching of fine and applied arts is not significant.

5. There is no significant relationship between Participants and solutions in mitigating the adverse effect of COVID-19 lockdown on the teaching of fine and applied arts.

\section{Method}

\section{Description of the study location}

We did the study in Benue State, Kogi State and Enugu State, Nigeria. Benue State occupies $34,059 \mathrm{~km} 2$ approximately. Benue State has a boundary on the south by Cross River, Ebonyi, and the Enugu States, in the west by Kogi State, in the north by Nassawara State, and in the NorthEast by Taraba State. The area is occupied by the Tiv the Idoma. The 
area of Kogi State is $29,833 \mathrm{~km} 2$. It has a boundary with Nassawara State and Kogi State in the northeast; Benue to the East; Enugu State, Anambra State, and Delta State to the south; Ondo State, Ekiti State, and Kwara State to the west; and Niger State to the north. Abuja federal capital territory additionally borders Kogi to the north. They are Igbira people. And the geographical area of Enugu State is 7, 161km2. It has boundaries with Kogi State and Benue State in the north, Enugu State, and Ebonyi State in the east, Abia State in the south, and Anambra State in the west. They are mainly Igbo people.

\section{Study design and population}

We used a cross-sectional survey design (Fraenkel \& Wallen, 2009). The sampling frame, from the colleges of education, records comprised all the fine and applied arts college students (447) and academics (61), whilst those randomly decided on (224) through the proportional to length sampling method has been the observed population. The colleges of education had been a College of Education Ankpa, Benue State; Federal College of Education, Okene, Kogi State; and College of Education Technical, Enugu State.

\section{Sampling technique}

We used a stratified sampling method. The whole number of respondents in the colleges of education was obtained through a proportional sampling to size approach. The summation of the two categories of respondents (508) became used to calculate proportions for lecturers (61), and college students (447) respectively. We have stratified the respondents into colleges of education based on their representativeness (range), with simple random sampling used to discover respondents among various schools within the college of education Ankpa, Benue State; Federal College of Education, Okene, Kogi State; and College of Education Technical, Enugu State respectively. Underneath put forward, the population spread in line with the colleges of education: 
Effective Use of Remote Learning

STUDENT

COE, Ankpa

FCE, Okene

COET, Enugu
133

162

152
LECTURER

18

23

20
TOTAL

151

185

172

Sample Size Determination

The taro Yamané's components below become used to calculate the pattern size of the respondents that took part in the observation. In step with Taro Yamané for a 95\% selfassurance degree and $p=0.05$, the dimensions of the pattern need to be.

$\mathrm{n}=\frac{\mathrm{N}}{1+\mathrm{N}\left(\mathrm{e}^{2}\right)}$

Where $N$ is the population size and $e$ is the level of precision.

We used this formula for the population, in which $N=508$ with $\pm 5 \%$ precision.

Assuming a 95\% confidence level and $p=0.5$, we get the sample size as

$\mathrm{n}=\frac{508}{1+508(.05)^{2}}=$

The desired sample size $n=224$

We calculated sample sizes for different schools from their respective population, which we gathered during our investigation. The calculations below show the sample values and their respective proportions.

$$
\begin{array}{cccc}
\text { COE, Amkpa } \begin{array}{c}
(151 / 508) 100 \%) \\
(30 / 100)(224)
\end{array}=67 & =30 \% \\
\text { FCE, Okene } \begin{array}{c}
(185 / 508) 100 \%) \\
(36 / 100)(224)
\end{array} & =81 & =36 \% \\
\text { COET, Enugu }(172 / 508) 100 \%) & & =34 \% \\
(34 / 100)(224) & =76 &
\end{array}
$$


However, out of 224 respondents, 218 were eventually used for the study. Six of the respondents did not submit their questionnaires. $43(20 \%)$ lecturers and $175(80 \%)$ were used for the study.

\section{Data collection and analysis}

We conducted the study between February and April 2021. The study utilized an improved version of the validated data collection questionnaire. The study instruments were pretested at a dissimilar college of education from the one we used for the study. The college of education is similar to the colleges of education we used for the study. We had corrected earlier errors and ambiguous questions before field data collection.

\section{Materials}

The study instruments had sections on demographic data, available ICT devices, effective techniques, challenges and solutions in mitigating the adverse effect of COVID-19 in the teaching of fine and applied arts. The researchers prepared the questionnaire, Effective Use of Remote Learning (EURL). The respondents returned filled instruments that were used in the study; a response rate of $97 \%$.

\section{Data analysis}

We checked and cleaned the information amassed for completeness and accuracy. The questionnaires had been coded, entered, and analyzed using IBM-SPSS version 25 . We tested the data within the questionnaires for internal consistency and had a completely excessive Cronbach's $\alpha$ value of 0.91 , which suggests a high degree of internal consistency for our scale that comprised 59 study items. We presented demographic characteristics and other univariate variables through summary facts using frequency/percentages for categorical variables. 
Likewise, the questionnaire correspondingly had $17,13,24$, and 5 items on available ICT devices, effective technique, challenges and solutions. The available ICT devices were measured by a 2-point scale: “Available," "Not Available," for research questions 1; effective techniques were measured by a 2-point scale: "Use," "Not Use," for research question 2; challenges were also measured by a 2-point scale "Challenge." "Not a Challenge," for research question 3 while solutions were measured by a 2-point scale "Agree," "Disagree" for research question 4.

For bivariate analysis, Chi-square statistics were used to measure the type of association between respondents and available ICT devices, effective techniques, challenges, and solutions by the Pearson Chi-square statistics, with the level of significance at $<5 \%$.

\section{Inclusion and exclusion criteria}

This study was limited to three colleges of education in Benue State, Kogi State and Enugu State, Nigeria that offer fine and applied arts and other art-related courses. The three colleges of education were Federal College of Education, Okene, College of Education Ankpa and College of Education Technical, Enugu.

\section{Demographic characteristics of respondents}

We presented the demographic features of respondents in Table 1. The study revealed that over half (218) respondents were students while $56 \%$ were females. The mean age (SD) of respondents was $37.58 \pm 20.18$ years, while $117(53.67 \%)$ were between 17 and 28 years. In this research, students were $80 \%$ and lecturers $20 \%$.

Table 1: Demographic characteristics of respondents

\begin{tabular}{lll}
\hline $\begin{array}{l}\text { Description of } \\
\text { variables }\end{array}$ & $\begin{array}{l}\text { Frequency } \\
\text { (n) }\end{array}$ & $\begin{array}{l}\text { Percentage } \\
(\%)\end{array}$
\end{tabular}

The age range of respondents $(n=218)$ 


\begin{tabular}{lcl}
\hline$\leq \mathbf{1 7}$ & 71 & 32.6 \\
$\mathbf{1 8 - 2 8}$ & 46 & 21.1 \\
$\mathbf{2 9 - 3 8}$ & 39 & 17.9 \\
$\mathbf{3 9 - 4 8}$ & 30 & 13.8 \\
$\mathbf{4 9 - 5 8}$ & 21 & 9.6 \\
$\mathbf{5 9 - 6 8}$ & 11 & 5 \\
Gender $(\boldsymbol{n}=\mathbf{2 1 8})$ & & \\
Male & 96 & 44 \\
Female & 122 & 56 \\
Respondents $(\boldsymbol{n}=\mathbf{3 9 2})$ & \\
Students & 175 & 80 \\
Lecturers & 43 & 20 \\
\hline
\end{tabular}

\section{Results}

\section{Effective Use of Remote Learning in Sustaining Teaching of Fine and Applied Arts}

Data in Table 2 on the availability of ICT devices that provide the best prospect for teaching and learning fine and applied arts showed the scores of items $1,2,3,4,5,9,10,12$, $13,14,15,16$, and 17 . These scores showed that items $1,3,5,7,13$ and 15 are available ICT devices while items $2,4,6,8,9,10,11,12,14,16$ and 17 revealed that the ICT devices are not available. However, Table 3 indicated that items 18 to 30 with a low percentage below $50 \%$ underuse. These scores showed that respondents do not use the effective technique for teaching fine and applied arts in remote learning. The data in Table 4 showed that items 31 to 54 with high frequency and percentage above $50 \%$ under Challenge. These scores indicated that respondents established that there are challenges concerning the use of technology in the teaching of fine and applied arts. Besides, Table 5 showed that items 55 to 59 with high frequency and percentage above 50\% under Agree. These scores showed that respondents 
agree on the solutions in mitigating the adverse effect of COVID-19 lockdown on teaching fine and applied arts.

Table 2: Frequency percentage of respondents on the available ICT devices that provide the best prospect for the teaching of fine and applied arts in colleges of education

$$
(n=218)
$$

\begin{tabular}{llllll}
\hline S/N & ITEM & \multicolumn{2}{c}{ Available } & \multicolumn{2}{c}{ Not Available } \\
\hline & & Frequency & Percent & Frequency & Percent \\
1. & Basic mobile phone & 178 & 81.7 & 40 & 18.3 \\
2. & Smart feature phone & 67 & 30.7 & 151 & 69.3 \\
3. & Smartphone & 169 & 77.5 & 49 & 22.5 \\
4. & Tablet & 81 & 37.2 & 137 & 62.8 \\
5. & Desktop/Laptop Computers & 127 & 58.3 & 91 & 41.7 \\
6. & Digital Camera & 52 & 23.9 & 166 & 76.1 \\
7. & Multimedia Projector & 128 & 58.7 & 90 & 41.3 \\
8. & Radio & 93 & 42.7 & 125 & 57.3 \\
9. & Television & 63 & 28.9 & 155 & 71.1 \\
10. & Interactive Smartboard & 45 & 20.6 & 173 & 79.4 \\
11. & Microphones & 88 & 40.4 & 130 & 59.6 \\
12. & Scanners & 86 & 39.4 & 132 & 60.6 \\
13. & Printers & 203 & 93.1 & 15 & 6.9 \\
14. & Light Pen & 16 & 7.3 & 202 & 92.7 \\
15. & MP3/MP4 & 139 & 63.8 & 79 & 36.2 \\
16. & VCD/DVD Player & 1 & 5 & 217 & 99.5 \\
17. & IPads & 18 & 8.3 & 200 & 91.7 \\
\hline
\end{tabular}

KEY: Benchmark for Available: $1-49 \%=$ Not Aware, $50-100 \%=$ Available; then for Not Available: $1-49 \%=$ Available, $50-100 \%=$ Not Available

Table 3: Frequency percentage of respondents on the effective technique used for the teaching of fine and applied arts in remote learning $\quad(n=218)$

\begin{tabular}{llllll}
\hline S/N & ITEM & \multicolumn{2}{c}{ Use } & \multicolumn{2}{c}{ Not Use } \\
\hline & & Frequency & Percent & Frequency & Percent \\
18. & Get to know your platform & 39 & 17.9 & 179 & 82.1 \\
19. & Create an online classroom & & & & \\
& environment & 50 & 22.9 & 168 & 77.1 \\
20. & Engage with your learners online & 51 & 23.4 & 167 & 76.6 \\
$\mathbf{2 1}$. & Be organized & 55 & 25.2 & 163 & 74.8 \\
22. & Use a variety of instruction strategies & 74 & 33.9 & 144 & 66.1 \\
23. & Be present & 64 & 29.4 & 154 & 70.6 \\
$\mathbf{2 4}$ & Provide ongoing feedback & 71 & 32.6 & 147 & 67.4 \\
$\mathbf{2 5}$. & Collaborate with other teachers & 49 & 22.5 & 169 & 77.5 \\
\hline
\end{tabular}




\begin{tabular}{llcccc}
\hline 26. & Reflect the lessons & 36 & 16.5 & 182 & 83.5 \\
27. & Maximize your professional & & & & \\
& development & 58 & 26.6 & 160 & 73.4 \\
28. Use online resources & 34 & 15.6 & 184 & 84.4 \\
29. & 70 & 32.1 & 148 & 67.9 \\
30 & Maktablish your presence right away assignments clear & 93 & 42.7 & 125 & 57.3 \\
\hline KEY: Benchmark for Use: $1-49 \%=$ Not Use, $50-100 \%=U$ se; then for Not Use: $1-49 \%=$ Use, \\
$50-100 \%=$ Not Use
\end{tabular}

Table 4: Frequency percentage of respondents on challenges concerning the use of technology in the teaching of fine and applied arts

$$
(\mathrm{n}=218)
$$

\begin{tabular}{llllll}
\hline S/N & Challenges & Challenge & & \multicolumn{2}{c}{ Not a Challenge } \\
\hline & & Frequency & Percent & Frequency & Percent \\
31. & Professional training & 172 & 78.9 & 46 & 21.1 \\
32. & Resistance to change & 158 & 72.5 & 60 & 27.5 \\
33. & Network infrastructure & 125 & 57.3 & 93 & 42.7 \\
34. & Unrialable device/software options & 164 & 75.2 & 54 & 24.8 \\
35. & Scheduling problem & 140 & 64.2 & 78 & 35.8 \\
36. & Poor online contents & 158 & 72.5 & 60 & 27.5 \\
37. & Technical issues & 191 & 87.6 & 27 & 12.4 \\
38. & Learners being left behind & 149 & 68.3 & 69 & 31.7 \\
39. & Distractions & 183 & 83.9 & 35 & 16.1 \\
40. & Lack of in-person interaction & 110 & 50.5 & 108 & 49.5 \\
41 & Staying motivated & 158 & 72.5 & 60 & 27.5 \\
42. & Understanding course expectations & 147 & 67.4 & 71 & 32.6 \\
43. & Time management & 183 & 83.9 & 35 & 16.1 \\
44. & Adaptability struggle & 190 & 87.2 & 28 & 12.8 \\
45. & Computer literacy & 154 & 70.6 & 54 & 29.4 \\
46. & Online learning is boring & 177 & 81.2 & 41 & 18.8 \\
47. & Technical difficulties & 158 & 72.5 & 60 & 27.5 \\
48. & Time for online training & 115 & 52.8 & 103 & 47.2 \\
49. & Unfamiliar technology & 183 & 83.0 & 35 & 16.1 \\
$\mathbf{5 0 .}$ & Uncertainty about the future & 157 & 72.0 & 61 & 28.0 \\
$\mathbf{5 1 .}$ & Personalized learning & 175 & 80.3 & 43 & 19.7 \\
$\mathbf{5 2}$. & Formative assessment & 170 & 78.0 & 48 & 22.0 \\
$\mathbf{5 3 .}$ & MOOCS & 150 & 68.8 & 68 & 31.2 \\
$\mathbf{5 4}$ & Informal learning & 86 & 39.4 & 132 & 60.6 \\
\hline
\end{tabular}

KEY: Benchmark for Challenge: $1-49 \%=$ Not a Challenge, $50-100 \%=$ Challenge; then for Not a Challenge: $1-49 \%=$ Challenge, $50-100 \%=$ Not a Challenge

Table 5: Frequency percentage of respondents on the solutions in mitigating the adverse effect of COVID-19 lockdown on the teaching of fine and applied arts 
$(\mathbf{N}=147)$

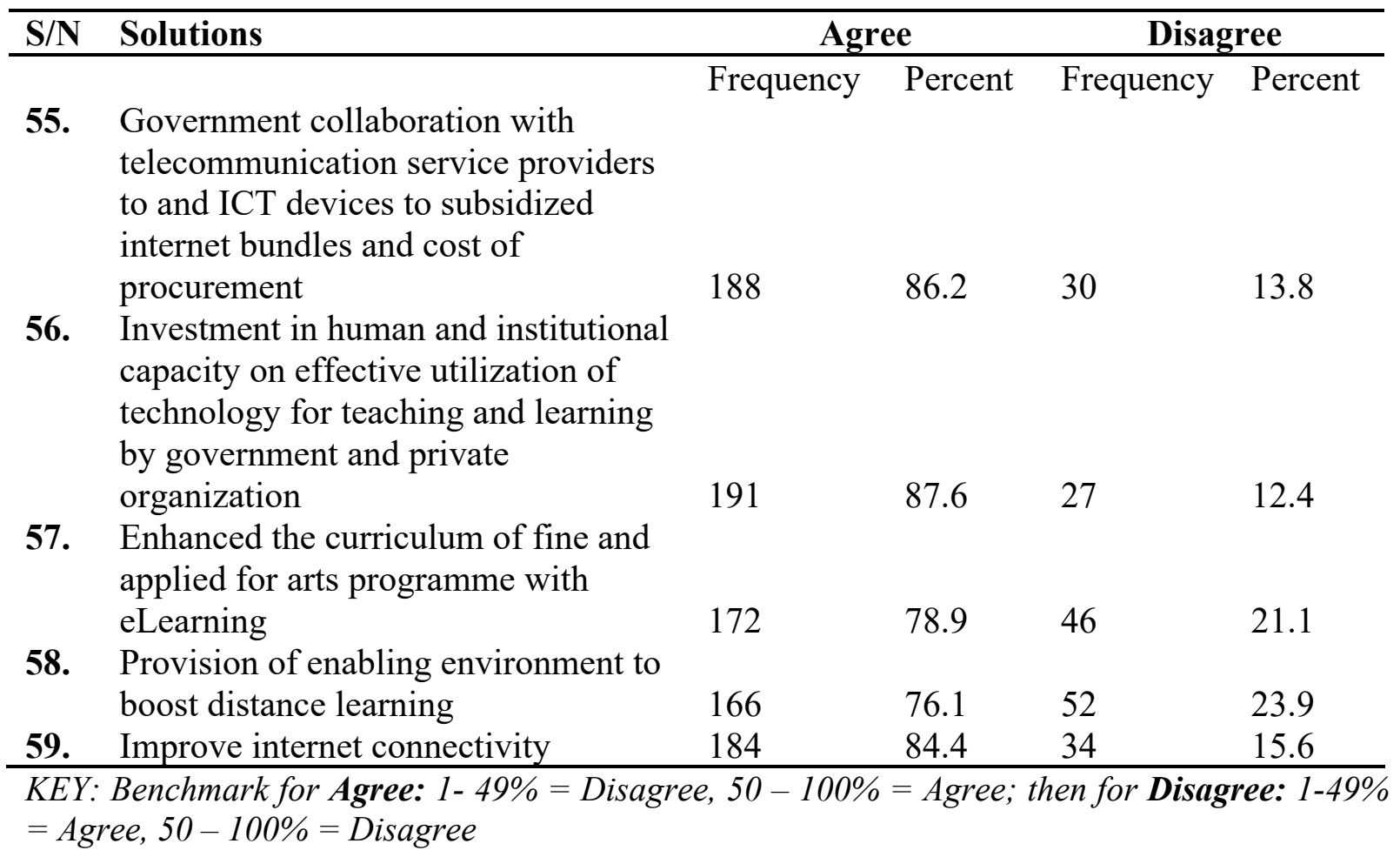

The measure of association among demographic indices and effective use of remote learning in sustaining teaching of fine and applied arts in the COVID-19 era

The study showed statistically significant associations between respondents and available ICT devices $\chi^{2}=.3 .890,1, p=.049$ as shown in Table 6 while the association of respondents and effective technique used for the teaching of fine and applied arts in remote learning was not significant $\chi^{2}=.423,1, p=.515$ (Table 7). As well, Table 8 revealed the association of respondents and challenges concerning the use of technology in the teaching of fine and applied arts was not significant $\chi^{2}=.138,1, p=.710$ whereas respondents associated with the solutions in mitigating the adverse outcome of COVID-19 lockdown on the teaching of fine and applied arts were statistically significant $\chi^{2}=4.205,1, p=.040$ as shown in Table 9.

Table 6: Relationship between participants and ICT devices that provides the best prospect for teaching and learning of fine and applied arts 


\begin{tabular}{lllc}
\hline RESPONDENTS & AVAILABLE & NOT AVAILABLE & TOTAL \\
\hline Students & $50(28.6 \%)$ & $125(71.4 \%)$ & 175 \\
Lecturers & $19(44.2 \%)$ & $24(55.8 \%)$ & 43 \\
\hline
\end{tabular}

Chi-Square, $\chi^{2}=3.890,1, p=.049$ (Significant)

Table 7: Relationship between participants and effective technique used for the teaching of fine and applied arts in remote learning

\begin{tabular}{llll}
\hline RESPONDENTS & USE & NOT USE & TOTAL \\
\hline Students & $56(32.0 \%)$ & $119(68.0 \%)$ & 175 \\
Lecturers & $16(37.2 \%)$ & $27(62.8 \%)$ & 43 \\
\hline
\end{tabular}

Chi-Square, $\chi^{2}=.423,1, p=.515$ (Not Significant)

Table 8: Relationship between participants and challenges concerning the use of technology in the teaching of fine and applied arts

\begin{tabular}{llll}
\hline RESPONDENTS & CHALLENGE & $\begin{array}{l}\text { NOT A } \\
\text { CHALLENGE }\end{array}$ & TOTAL \\
\hline Students & $131(74.9 \%)$ & $44(25.1 \%)$ & 175 \\
Lecturers & $31(72.1 \%)$ & $12(27.9 \%)$ & 43 \\
\hline
\end{tabular}

Chi-Square, $\chi^{2}=.138,1, p=.710$ (Not Significant)

Table 9: Relationship between participants and solutions in mitigating the adverse effect of COVID-19 lockdown on the teaching of fine and applied arts

\begin{tabular}{llll}
\hline RESPONDENTS & AGREE & DISAGREE & TOTAL \\
\hline Students & $134(76.6 \%)$ & $41(23.4 \%)$ & 175 \\
Lecturers & $39(90.7 \%)$ & $4(9.3 \%)$ & 43 \\
\hline
\end{tabular}

Chi-Square, $\chi^{2}=4.205,1, p=.040$ (Significant)

\section{Discussion}

The research objective was on the effective use of remote learning in sustaining teaching of fine and applied arts in the covid-19 era in colleges of education in Benue State, Kogi State and Enugu State, Nigeria. The results showed that the ICT devices are not available for teaching fine and applied arts, The lecturers do not use the effective technique for teaching fine and applied arts in remote learning, respondents ascertained that there are challenges concerning the use of technology in the teaching fine and applied arts, and they also agree on the solutions in mitigating the adverse effect of COVID-19 lockdown on 
teaching fine and applied arts. This was indicated by high percentage ratings by the participants. The study also revealed a statistically significant relationship between participants and the ICT devices: $\chi^{2}=.3 .890,1, p=.049$. The relationship between participants and effective techniques used for teaching fine and applied arts in remote learning was not significant $\chi^{2}=.423,1, \mathrm{p}=.515$. The relationship between participants and challenges concerning the use of technology in the teaching fine and applied arts was not significant $\chi^{2}=.138,1, p=.710$ and the relationship between participants and the solutions in mitigating the adverse effect of COVID-19 lockdown on teaching fine and applied arts were statistically significant $\chi^{2}=4.205,1, p=.040$

This may have led them not to make available technologies and other facilities that will enhance effective teaching in the schools in this COVID-19 era. It could also be as a result that the school authorities fail to see the need to equip schools with adequate remote learning facilities for proper teaching fine and applied arts. It is quite alarming lecturers do not use effective techniques for teaching fine and applied arts in remote learning. This may have been caused by not possessing the required skills in content delivery using modern technologies associated with remote learning. Some of the lecturers and students are still analogue in handling the ICT equipment and facilities. Where there are some of this ICT equipment and facilities, they usually pack them in a safe place in the schools for fear of damages without making use of them. There is a shortage of technical officers and technologists that can assist the lecturers and students in using these facilities for teaching fine and applied arts.

Challenges are hindering the effective use of remote learning. This may be because schools do not have enough preparation for this sudden change caused by COVID-19 lockdown in content delivery through an online format. The schools were closed with very short notice. Hence, modern ICT equipment and materials were not on the ground for an effective take off for remote learning. The lecturers and students were not given enough time 
to train maximally for the new approach to learning. They resorted to be using the one they could lay their hands on which is grossly appropriate for remote learning. The study also found out some measures every stakeholder in the education business should imbibe for efficient and effective remote teaching and learning of fine and applied arts in colleges of education. These measures if given necessary attention will ensure a very smooth implementation of remote learning in the colleges of education.

\section{Conclusions}

Based on the findings, it was concluded that the ineffective use of technology in the teaching and learning of fine and applied arts in colleges of education stem from government insensitivity to the importance of technology in education. Several devices like smart feature phones, smartphones, tablets, PC's, laptops, projectors, radio and TV. These devices have been confirmed to be effective in aiding education in or out of class. Remote learning can be used for effective and efficient teaching fine and applied arts if infrastructures such as devices, network connection, data bundles and power are readily available and accessible by students and teachers.

\section{Recommendations}

1. The paper recommends the government should collaborate with telecommunication service providers to subsidized internet bundles so that more people can have access to data.

2. Educators like lecturers of fine and applied arts need to be trained in digital skills. This will go a long way in adding to the nation's human capital. 
Effective Use of Remote Learning

3. There is also a need for the government to support the educational institutions with adequate infrastructures needed for the effective implementation of online classes. 


\section{References}

Bao, X., Qu, H., Zhang, R. \& Hogan, T. P. (2020). Modelling reading ability gain in kindergarten children during COVID-19 school closures". International Journal of Environmental Research. Public Health. 17: 17. doi:10.3390/ijerph17176371.

Barbara, S. G. \& Leong, P. (2020). The art of online learning: Teaching visual art virtually. Hawaii: Leeward Community College. Retrieved from http://www2.hawaii.edu/ peterleo/Electronic_Portfolio/OnlineVisualArt.pdf.

eLearning Africa (2020). The effect of Covid-19 on education in Africa and its implications for the use of technology. Retrieved from http://www.guninetwork.org/files/the_effect_of_covid 19_on_education_in_africa.pdf

Fraenkel, J. R., \& Wallen, N. E. (2009). How to design and evaluate research in education. New York, NY: McGraw-Hill Companies, Inc.

Lee, L. (2020). The show must go online: Arts teachers adapt to at-home instruction from laundry art to name that tune, arts enrichment teachers are finding creative ways to transition to remote teaching. Retrieved from https://www.edutopia.org/article/showmust-go-online-arts-teachers-adapt-home-instruction

Mayo Clinic (2019). Coronavirus disease 2019 (COVID-19). Retrieved from https://www.mayoclinic.org/diseases-conditions/coronavirus/symptoms-causes/syc20479963

Onyema, E. M., Nwafor, C. E., Obafemi, F. A., Shuvro, S., Atonye, F. G., Aabha, S. \& Alhuseen, O. A. (2020). Impact of coronavirus pandemic on education. Journal of Education and Practice, 11 (13), 108-121.

Rumble, G. (2019). The Planning and Management of Distance Education. London: Routledge. https://doi.org/10.4324/9780429288661.

Stewart, M. (2006). Teaching art at a distance. Retrieved from https://elearnmag.acm.org/archive.cfm?aid=1190072.

UNESCO (2020a). Education: From disruption to recovery. Retrieved from https://en.unesco.org/covid19/educationresponse

UNESCO (2020b). 290 million students out of school due to COVID-19: UNESCO releases first global numbers and mobilizes response. Retrieved from https://en.unesco.org/news/290-million-students-out-school-due-covid-19-unescoreleases-first-global-numbers-and-mobilizes

World Bank (2020). Nigeria is trying COVID-19: Laying foundations for a strong recovery. Washington: World Bank Publication.

World Health Organization (WHO) (2020). WHO Director-General's opening remarks at the media briefing on COVID-19 - 11 March 2020. https://www.who.int/directorgeneral/speeches/detail/who-director-general-s-opening-remarks-at-the-mediabriefing-on-covid-19---11-march-2020. 
Effective Use of Remote Learning

Yamane T. (1967). Statistics: An Introductory Analysis. 2nd ed. New York, NY: Harper and Row. 